\title{
THE USE OF LISTENING LOGS THROUGH WHATSAPP IN IMPROVING LISTENING COMPREHENSION OF EFL STUDENTS
}

\author{
1Iwan Fauzi; 2 Putri Angkasawati \\ 1,2Universitas Palangaraya \\ Corresponding email: i_fauzi@edu.upr.ac.id
}

\begin{abstract}
The objective of this study is to find out the effect of using listening logs through WhatsApp on listening comprehension of EFL students in the Department of English Education of Palangka Raya University. The listening comprehension of students is categorized low which hampers their proficiency in English. Then an experiment is done to improve students' comprehension in listening skill by using listening logs through WhatsApp application on smartphones. The experiment treated in this study was to make a learning group of WhatsApp by inviting the students joining the group. The experiment was held for three weeks which practiced four aspects of listening comprehension: (1) identifying main ideas or main gists, (2) identifying supporting details, (3) identifying moods of message, and (4) developing new vocabularies. There were 40 students ( 24 females and 16 males) fulfilling the sample of the study taken from the second year EFL students of English study program at Palangka Raya University. The method used in this study was pre-experimental design by choosing the type of one group pretestposttest design. The pretest and posttest evaluation results were analyzed using non-parametric test of Wilcoxon Signed-ranks by tworelated samples statistical analysis to find out the significance of the experiment given. The study concludes that the practice of listening through listening logs in WhatsApp gives significant improvement in listening comprehension to EFL learners.
\end{abstract}

Keywords: listening logs, WhatsApp, EFL students

\section{INTRODUCTION}

Among four skills that are taught to English as a foreign language (EFL) students, many researchers believe that listening and speaking are the most important skills (Bano, 2017). Bress in Bano (2017) states that listening skill is important because humans start listening since babies before being able to speak. He pointed out that listening must be the most practiced skill to communicate. 
Listening comprehension is the process of understanding spoken materials using aural organs. Celik, Yidliz, and Tugrul Mart in Gilakjani and Sabouri (2016) defined listening comprehension as one's ability to recognize another through sense, aural organs and allocate a meaning to the message to understand. Beyond understanding meanings and supporting details in spoken materials, listening also includes listening for thoughts, feelings, and intentions of the speakers in delivering the message (Pourhossein, Gilakjani and Ahmadi, 2011). Listening comprehension is not only hearing. After listeners hear the message, they should be able to form a meaning in their mind as one of the necessary parts in making successful communication (Rost in Ahmadi, 2016).

When language learners are listening to other people's utterance, they are not only hearing sounds in utterance-they are expected to receive messages carried in the utterance by mental processing the spoken materials into something that is understandable. Brown (2006) states that there are two processes in making the understandable input (i.e., in listening comprehension): top-down and bottom-up processing. Top-down processing means using prior knowledge and experiences that are similar to the new input in order to understand it - by guessing and inferrring what can the input be about (i.e., main idea); bottom-up means using the information we have about linguistic elements: sounds, word meanings, and discourse markers to understand the input in details. As listening comprehension is a process that happens mentally, it needs active involvement, effort, and practice by the language learners.

In EFL context difficulties in listening might raise during the process because the learners are still lacking in the language's background knowledge as it is a new thing. There are certain studies by Lynch as stated in Bano (2017) which demonstrate that listening to second language is not too far different from the process of first language listening, only that the second language listeners have a limited knowledge of the language. A limited knowledge of the language includes the knowledge of cultural differences, accent, vocabulary, length or speed of the language input; which are considered as some major problems the language learners face with listening comprehension (Azmi Bingo, Celik, Yidliz, and Tugrul Mart, 2014). Adding more listening practice will help the EFL learners to cope with this situation.

More listening practice can be implemented through extensive listening. Extensive listening is an out-of-class listening that provides students to use any listening materials outside the classroom to increase the exposure to the spoken language (Vandergriff and Goh, 2012). Extensive listening consists of listening activities beyond the classroom-based listening setting. This type of listening focuses on giving language learners more 
exposure to listening materials by considering the fact that they have more time than when they are doing listening in the classroom.

Why extensive listening should be taken into account to EFL students. This is due to the fact that the great exposure of listening materials and time in extensive listening encourage learners' motivation to practice and continue practicing in their own time (Lynch in Milliner, 2017). It is ideal for learners in EFL context who need as much practice as possible to master the new language. Extensive listening also advocates the learners to be exposed to different types of discourse, e.g., dialogic speech, accents, and cultures (Gilliland in Milliner, 2017). It also helps the learners cope with the major difficulties they face in listening comprehension.

In this digital era, forming a language learning community is not difficult. There are many technology-based tools or applications for language learners to create their own learning communities by offering various services to make the extensive listening experience with peers happen. Teachers can also use this to facilitate their students to do extensive listening as an extended teaching-learning practice by creating learning communities as well. Some examples of technology-based tools that can be used are WhatsApp, Yahoo Messenger and Line. WhatsApp (henceforth named as WA) is a popular social networking application which allows the users to send and receive texts, audio, photos, videos, documents, location, voice calls, and creating groups. The accessibility of WA in most smartphone and computer devices is a great opportunity to maximize the time and place flexibility of extensive listening activities. The learners do not need to prepare any meetings in a specific place and time to do listening exercise together. They only need to access their WA, create group, and communicate through it. By considering the accessibility of WA, this study used it as a platform to do an extensive listening by using a strategy called listening logs.

Logs, journals, or portfolios are purposeful collection of students work that demonstrates to the students and others dealing with their efforts, progress, and achievements in given areas. In other words, logs give assistance that record learners activity in experiencing the materials, help in reflecting of what they have learned, think about what they have learned, and act out their comprehension through the logs (Genesee and Upshur in Sharifi and Hassaskhah, 2011). Listening logs, also called as listening journals, listening diaries, or listening portfolios have already been used to study the process of language learning and teaching since the late 1970s (Chen, 2016). The strategy of using logs in listening activities is still continuing today.

Furthermore, as stated by Gilliland in Nunan and Richards (2015: 13) listening logs are as an ongoing assignment through which students 
document their participation in out-of-class activities. She further stated that listening logs require students to take variety of materials, take notes on the content, and reflect on their comprehension of each material they listened to. Specific goals can be set, then the goals will be controlled regularly by listening logs.

Using listening logs through WA means combining the self-learning of using listening logs with peer-learning (i.e. learning in groups) through discussion and other learners' shared listening logs which are conducted through a group in WA. In addition, listening logs through WA is a strategy which means that the activities of listening are recorded in listening logs and communicated through WA. The use of WA is to point out the accessibility of this application as a medium of implementing listening activities through which listening logs are used in it. Starting from making a learning group; then it is continued by sending and playing audio materials through the platform or links to outside audio sources; sending the listening logs worksheets; and making discussions about the contents in the listening logs and about the listening activity itself through group-chatting.

There have been many studies conducted about the effect of listening logs on listening skill. A study carried out by Gilliland (2015) reported on intermediate and advanced ESL students' perceptions of extensive listening logs. The study revealed that the listening log had encouraged the students to try out new genres of listening contents. The students also make improvements in listening and critical thinking skills. Then, Galloway and Rose (2014) reported on Japanese students' experiences with different varieties of English. The study was found that recording listening logs increased the students' exposure to global English varieties and motivate them to reevaluate personal prejudices against certain varieties. Another study by Kemp (2010) found out that using a listening log helped EFL students in a British university developed independent learning skills, including monitoring their own performance and progress, making decisions on their learning, and acting upon them. In addition, Chen (2016) reported the effect of extensive listening on her Taiwanese students by maintaining listening logs. It gives effects on the students' future study planning, the gaining of new knowledge, improvement in listening skills, and an increase in confidence.

Related to the use of WA as a medium to carry out the logs in language learning, there are still few discussions revealing this popular smartphone application in the field of language teaching. This is probably due to the fact that it is still a new medium in language learning. Two studies about the use of WA revealed here are related to teaching and learning in general, not to specify in a particular subject of teaching, i.e., English. Rambe and Bere (2013), for instance, examined the use of WA in a 
South African university. The students gave the positive feedback and claimed that it was an easier way to communicate with their teachers and the rest of the class and it was also fun. Another study about WA as a learning medium has been conducted by Bansal and Joshi (2014) who revealed that married students found learning through WA is disruptive, but much younger students found favorable. From these two studies, WA as a learning medium seems more favorable for college students or at least positive because it is fun and has great accessibility to use.

Based on the discussion aforementioned, this study is related to the effect of using listening logs through WA on listening comprehension achievement of students in lower intermediate language level. There are two questions to be answered in this study; (1) is there any significant effect of the students' listening comprehension using listening logs through WhatsApp? And (2) what are aspects of listening comprehension improved after the students are facilitated in learning English using listening logs through WhatsApp?

\section{METHODS}

This study used pre-experimental design which took the type of one group pretest-posttest design. There were 40 students (24 females and 16 males) taken to fulfill the data of this study. The sample was taken from the second year EFL students of the English study program at Palangka Raya University that were considered to be passed the matriculaton course of four basic English skills by level-one (listening, speaking, reading, and writing). The subjects were given an achievement test before and after doing experiments. The pretest and posttest results were analyzed using nonparametric test of Wilcoxon Signed-ranks by two-related samples of statistical analysis to find out the significant effect of the experiment. The achivement test was adapted from Listening Diagnostic Test based on Phillips (2001) which was regarded to be standard to the level of university students. There were 40 items to be tested which represented four aspects of listening comprehension: (1) identifying main ideas or main gists, (2) identifying supporting details, (3) identifying moods of message, and (4) developing new vocabularies.

To confirm the vallidity of the test, the researcher asked two senior lecturers of English study program to rate the content of test. Both lecturers were agreed that the test content was suitable and could evaluate the students' comprehension on listening related to the four aspects. Then, Cronbach Alpha was used to count the reliability coefficient of the test which obtained the value .86. So, the researcher felt confident about the validity and the reliability of the test instrument. 
The experiment treated in this study was to make a learning group of WA then invite the subjects joining the group. An assistant of the researcher was acted as the group administrator to communicate with the subjects about the ethics of the learning group which were no use of absurd language, no personal remarks, and be active participation on the activities. The treatment was held for three weeks starting from May 28th to June 17th, 2018. In every week the subjects were asked to do the listening exercise by playing the provided audio and to record what they got from the activity into the listening logs. The following is the schedulle of weekly activities on the WA learning group.

Table 1. Weekly schedule of the learning group activity on WA

\begin{tabular}{ll}
\hline Day 1 & The format of listening logs was sent to each member of the \\
& learning group (shown on Appendix-1). \\
\hline Days 2 to 6 & The students were listening four audio-file materials in \\
& monologues or short conversations in which one audio file was \\
sent for one day. & The students wrote down what they conveyed from the audio \\
& into the listening logs based on the format given in which one \\
& audio file was one log-sheet to one day. \\
- On the day 6 at $11: 59$ p.m. the students should send the listening \\
log-sheet formats to the administrator of the group. \\
- The students discussed their logs and their weekly listening \\
experience with the group members and the researcher by- \\
chatting to find solutions to any problems relating with the \\
listening activities and the logs itself. \\
- On the discussion, the students were asked to reflect by revising \\
their logs or taking any notes of new information.
\end{tabular}

Table 2 below shows the summary of students' scores of listening comprehension before and after they were given treatments of learning group activity on WA (scores more details are shown on Appendix-2). 
The Use of Listening Logs through Whatsapp in Improving...

Table 2. Summary of students' scores (pre- and posttest) on listening comprehension

\begin{tabular}{llll}
\hline & N & Mean & $\begin{array}{l}\text { Std. } \\
\text { Deviation }\end{array}$ \\
\hline $\begin{array}{l}\text { Listening comprehension scores before } \\
\text { treatments }\end{array}$ & 40 & 57.062 & 9.2488 \\
\hline Listening comprehension scores after treatments & 40 & 73.937 & 7.4008 \\
\hline
\end{tabular}

Then, the scores of pretest and posttest on Table 2 are statitiscally calculated using non-parametric Wilcoxon test of two-related samples to find out the significance difference of both test scores.

Table 3. Score differences of listening comprehension in pretest and posttest

\begin{tabular}{llrrrrr}
\hline & & $\mathbf{N}$ & $\begin{array}{r}\text { Mean } \\
\text { rank }\end{array}$ & $\begin{array}{r}\text { Sum of } \\
\text { rank }\end{array}$ & Z & $\begin{array}{c}\text { Asymp. Sig. } \\
\text { (2-tailed) }\end{array}$ \\
\hline \multirow{3}{*}{$\begin{array}{l}\text { Score Posttest } \\
\text { - Score Pretest }\end{array}$} & Negative Ranks & $0^{\mathrm{a}}$ & .00 & .00 & & \multirow{2}{*}{$\mathbf{0 0 0}$} \\
\cline { 2 - 6 } & Positive Ranks & $40^{\mathrm{b}}$ & 20.50 & 820.00 & $\mathbf{5 . 5 3 2}$ & \\
\cline { 2 - 5 } & Ties & $0^{\mathrm{c}}$ & & & & \\
\cline { 2 - 4 } & Total & & & & \\
\hline
\end{tabular}

Table 3 shows that there is a significant difference in listening comprehension after three weeks treatment of using listening logs through WA. The data shows that all students scored higher in posttest than pretest, and none students scored lower than pretest nor student maintained the scores as same as the pretest. Hence the treatments given to the subjects succeed to improve students' listening comprehension. This is specified by statistical test values where $Z(1.96)=5.53, \mathrm{p}<.001$.

In relation with the aspects of listening comprehension improvement after the students are facilitated using listening logs through WA, four aspects of comprehension namely identifying main ideas or main gists, identifying supporting details, identifying moods of message, and developing new vocabularies are also statistically calculated through Wilcoxon tests.

Table 4 Comprehension scores of identifying main ideas in pretest and posttest

\begin{tabular}{|c|c|c|c|c|c|c|}
\hline & & $\mathbf{N}$ & $\begin{array}{r}\text { Mean } \\
\text { rank }\end{array}$ & $\begin{array}{r}\text { Sum of } \\
\text { rank }\end{array}$ & $\mathbf{Z}$ & $\begin{array}{c}\text { Asymp. Sig. } \\
\text { (2-tailed) }\end{array}$ \\
\hline \multirow{4}{*}{$\begin{array}{l}\text { Score Posttest } \\
\text { - Score Pretest }\end{array}$} & Negative Ranks & $0^{\mathrm{a}}$ & .00 & .00 & \multirow{4}{*}{$-5.890^{a}$} & \multirow{4}{*}{.000} \\
\hline & Positive Ranks & $40^{b}$ & 20.50 & 820.00 & & \\
\hline & Ties & $0^{c}$ & & & & \\
\hline & Total & 40 & & & & \\
\hline
\end{tabular}

Table 4 shows that all students scored higher in posttest than pretest of identifying main ideas. None students scored lower than pretest nor student scored the same as the pretest. It clearly indicates that students' 
comprehension of identifying main ideas significantly improved after they treated with the listening logs on WA. This is specified by statistical test values where $Z(1.96)=5.90, p<.001$

Table 5 Comprehension scores of identifying supporting details in pretest and posttest

\begin{tabular}{|c|c|c|c|c|c|c|}
\hline & & $\mathbf{N}$ & $\begin{array}{r}\text { Mean } \\
\text { rank }\end{array}$ & $\begin{array}{r}\text { Sum of } \\
\text { rank }\end{array}$ & $\mathbf{Z}$ & $\begin{array}{l}\text { Asymp. Sig. } \\
\text { (2-tailed) }\end{array}$ \\
\hline \multirow{4}{*}{$\begin{array}{l}\text { Score Posttest } \\
\text { - Score Pretest }\end{array}$} & Negative Ranks & $5^{a}$ & 16.30 & 81.50 & \multirow{4}{*}{$-4.244^{a}$} & \multirow{4}{*}{.000} \\
\hline & Positive Ranks & $33^{b}$ & 19.98 & 659.50 & & \\
\hline & Ties & $2^{c}$ & & & & \\
\hline & Total & 40 & & & & \\
\hline
\end{tabular}

a. Based on negative ranks Wilcoxon signed Ranks Test

In the case of identifying supporting details, 5 out of 40 students scored lower, whereas 33 students scored higher in the post-treatment of listening comprehension test. Then, there were two students maintained their previous scores of comprehension. The data from the table clearly shows that there is a significant difference between students' comprehension scores before and after treatment with the listening logs on WA. This is specified by statistical test values where $Z(1.96)=4.24, \mathrm{p}<.001$.

Table 6 Comprehension scores of identifying moods of message in pretest and posttest

\begin{tabular}{|c|c|c|c|c|c|c|}
\hline & & $\mathbf{N}$ & $\begin{array}{r}\text { Mean } \\
\text { rank }\end{array}$ & $\begin{array}{r}\text { Sum of } \\
\text { rank }\end{array}$ & $\mathbf{Z}$ & $\begin{array}{l}\text { Asymp. Sig. } \\
\text { (2-tailed) }\end{array}$ \\
\hline \multirow{4}{*}{$\begin{array}{l}\text { Score Posttest } \\
\text { - Score Pretest }\end{array}$} & Negative Ranks & $0^{\mathrm{a}}$ & .00 & .00 & \multirow{4}{*}{$-5.705^{a}$} & \multirow{4}{*}{.000} \\
\hline & Positive Ranks & $40^{b}$ & 20.50 & 820.00 & & \\
\hline & Ties & $0^{c}$ & & & & \\
\hline & Total & 40 & & & & \\
\hline
\end{tabular}

Table 6 shows that all students scored higher in posttest than pretest of identifying moods of message. None students scored lower than pretest nor student scored the same as the pretest. It clearly indicates that students' listening comprehension significantly improved after treating them with the listening logs on WA. This is specified by statistical test values where $Z$ $(1.96)=5.70, \mathrm{p}<.001$.

Table 7 Comprehension scores of developing new vocabularies in pretest and posttest

\begin{tabular}{|c|c|c|c|c|c|c|}
\hline & & $\mathbf{N}$ & $\begin{array}{r}\text { Mean } \\
\text { rank }\end{array}$ & $\begin{array}{r}\text { Sum of } \\
\text { rank }\end{array}$ & $\mathrm{Z}$ & $\begin{array}{c}\text { Asymp. Sig. } \\
\text { (2-tailed) }\end{array}$ \\
\hline \multirow{4}{*}{$\begin{array}{l}\text { Score Posttest } \\
\text { - Score Pretest }\end{array}$} & Negative Ranks & $5^{a}$ & 10.50 & 52.50 & \multirow{4}{*}{$-4.137^{a}$} & \multirow{4}{*}{.000} \\
\hline & Positive Ranks & $28^{\mathrm{b}}$ & 18.16 & 508.50 & & \\
\hline & Ties & $7^{c}$ & & & & \\
\hline & Total & 40 & & & & \\
\hline
\end{tabular}


In the case of developing new vocabularies, 5 out of 40 students scored lower, whereas 28 students scored higher in the post-treatment of listening comprehension test than in the pretest. Then, seven students maintained their previous scores of comprehension. From the table, it clearly indicates that there is a significant difference between students' comprehension scores in developing new vocabularies before and after treatment with the listening logs on WA. It is specifically shown by statistical test values where $Z(1.96)=$ $4.14, \mathrm{p}<.001$.

\section{DISCUSSIONS}

In present study, the students were expected to enhance their listening comprehension by four criteria of achievement: (1) identifying main idea or main gist; (2) identifying supporting details; (3) identifying moods of message; and (4) developing new vocabularies. Using listening exercises on WA should not only be done in class, but it is also outside the classroom (extensive listening) where the students could allocate more times to plan the activities. By allowing the students to use listening log strategy-during the treatment, the students could get clear instructions of what information they should have found while listening. Moreover, by using WA those instructions given were listed on the listening logs and the students should have answered those instructions based on what they found while listening.

As this listening log strategy was carried out through a WA group where group members wanted to learn the same matters, the students did not only record their findings on listening logs and study it by themselves. Yet, they could also share the logs to the other members, to study them together or to give feedback through the logs in order that they could be used as additional information. By doing this - sharing the logs to the group may build a discussion and more information could be taken as many people as involved, instead some difficulties could be solved together in group.

Based on the result of this study, the use of listening logs through WA succeeds to improve significantly students' listening comprehension. This is due to the fact that it lets the students effectively get more information from listening materials since it could be practiced outside the classroom. Morever, the result of present study also confirms a study of Gilliland (2015) who found that the use of listening logs can give great influence on language learners' extensive listening. As listening to a new language takes practice and time, language learners have to do more than just listen to materials they also have to comprehend the contents well. By recording information they found while listening, learners can reflect on their comprehension toward the contents through the record they made. In addition, this current study also approves the results of Bansal and Joshi's (2014) study in which 
using WA is favorable as a learning medium because of its accessibility for teacher or students.

\section{CONCLUSION AND SUGGESTION}

This pre-experimental study indicates that with the practice of listening through listening logs on WA there are some significant improvements of listening comprehension made by EFL learners. The results of this study lead to two main conclusions. In general, the average score of EFL learners in listening comprehension increase significantly after treatments. None students score lower than before they involve in listening practice through listening logs on WA which means the treatment given is effective to improve their listening comprehension. In specific, EFL learners have excellent performance in identifying main ideas and identifying moods of message. By these two indicators of comprehension, the students' achievement improves very significantly without retaining any student to maintain the same scores on the two indicators evaluated before the treatment. Meanwhile, two other indicators of comprehension still retain some students unimproved in which 7 out of 40 students do not improve in identifying supporting details, and 12 out of 40 students are unimproved in the way of developing new vocabularies. However, both indicators of comprehension mentioned later are still significant in terms of their improvement effects.

Based on the result of this study, it recommends that WA can be used to help EFL learners in extensive listening activities along with listening logs because WA is the most popular application media in smartphones nowadays in terms of delivering message and sharing information. Another advantage of listening logs through WA is that this software application can be applied as a strategy of homework assignments by EFL teachers to their students. This is due to the fact that learning in a classroom is very limited in time, so that this strategy can be used to give students more opportunity to do listening activities outside the classroom since time is not restricted. Then, teachers can monitor their students what they have learned and check their students' improvement by looking at the listening logs that they have sent through the WA.

\section{REFERENCES}

Ahmadi, S. (2016). "The Importance of Listening Comprehension in Language Learning". International Journal of Research in English Education; 1(1): 7-10.

Azmi, B. M., Celik, B., Yidliz, N., and Tugrul, M. C. (2014). "Listening comprehension Difficulties Encountered by Students in Second 
The Use of Listening Logs through Whatsapp in Improving...

language Learning Class". Journal of Educational and Instructional Studies in the World; 4(4), 1-6.

Bano, F. (2017). "Towards Understanding Listening Comprehension in EFL Classroom: The Case of the Saudi Learners". English Language Teaching; 10(6): 21-27.

Bansal, T., \& Joshi, D. (2014). "A study of students experiences of WhatsApp mobile learning". Global Journal of Human-Social Science Research; 14(4): 28-33.

Brown, S. (2006). Teaching Listening. New York, NY: Cambridge University Press.

Chen, C. W. (2016). "Listening Diary in the Digital Age: Students' Material Selection, Listening Problems, and Perceived Usefulness". The JALT CALL Journal; 12(2): 83-101.

Galloway, N., and H. Rose. (2014). "Using Listening Journals to Raise Awareness of Global Englishes in E LT". ELT Journal; 68(4): 386-396.

Gilakjani, A. \& Sabouri, N. (2016). "Learners' Listening Comprehension Difficulties in English Language Learning: A Literature Review". English Language Teaching; 9(6): 123-133.

Gilliland, B. (2015). "Listening Logs for Extensive Listening Practice". In Language Learning Beyond the Classroom (pp. 13-22). D. Nunan \& J. C. Richards (Eds.). New York: Routledge.

Kemp, J. (2010). “The Listening Log: Motivating Autonomous Learning". ELT Journal, 64, 385-395.

Milliner, B. (2017). "Five online resources for extensive listening in the Japanese EFL classroom". Accents Asia; 9(2), 1-10.

Nunan, D., Richards, J. C. (2015). Language Learning Beyond the Classroom. New York, NY: Routledge.

Phillips, Deborah. (2001). Longman Complete Course for the TOEFL Test. New York: A Pearson Education Company

Pourhossein., Gilakjani, A., and Ahmadi, M. R. (2011). "A Study of Factors Affecting EFL Learners' English Listening Comprehension and the Strategies for Improvement". Journal of Language Teaching and Research; 2(5): 977-988.

Rambe, P., \& Bere, A. (2013). “Using mobile instant messaging to leverage learner participation and transform pedagogy at a South African University of Technology". British Journal of Educational Technology, 44(4), 544-561.

Sharifi, Ahmad., and Hassaskhah, Jalleh. (2011). “The Role of Portfolio Assessment and Reflection on Process Writing". Asian EFL Journal. Retrived from http://www.asian-efl-journal.com/PDF/March-2011as.pdf 20 May 2018. 
Iwan Fauzi, Putri Angkasawati

Vandergrift, L. \& Goh, C. (2012). Teaching and Learning Second Language Listening: Metacognition in Action. New York, NY: Routledge.

Wei, L. (2012). "Teaching listening in EFL classroom in senior high schools in Taiwan". Retrieved from http://english.tyhs.edu.tw/xoops/html/tyhs/teach_source101/06pl an in February 19th, 2018. 
The Use of Listening Logs through Whatsapp in Improving...

Appendix 1

The Format of Listening Logs

Date: Name:

Kind of Material: Dialogue/Narratiun

Audio title :

Main Idea : (write in one or two sentences. You can use English or Indonesia)

Details : (write supporting details that support your main idea in $5 \mathrm{~W}+1 \mathrm{H}$ )

Mood

Vocabulary : (list new vocabulary you found and the synonym from dictionary)

Is today's listening fun: Yes/Maybe/No

(Adapted from Wei, 2012) 


\section{Appendix 2}

Students' scores in listening comprehension

\begin{tabular}{|c|c|c|c|c|c|c|c|c|c|c|c|}
\hline \multirow{2}{*}{ No. } & \multirow{2}{*}{$\begin{array}{c}\text { Students' } \\
\text { labels }\end{array}$} & \multicolumn{5}{|c|}{ Scores of pretest } & \multicolumn{5}{|c|}{ Scores of posttest } \\
\hline & & 1 & 2 & 3 & 4 & Sum & 1 & 2 & 3 & 4 & Sum \\
\hline 1. & S001 & 12,5 & 7,5 & 10,0 & 20,0 & 50,0 & 20,0 & 17,5 & 12,5 & 20,0 & 70,0 \\
\hline 2. & S002 & 15,0 & 12,5 & 17,5 & 10,0 & 55,0 & 20,0 & 15,0 & 20,0 & 15,0 & $\mathbf{7 0 , 0}$ \\
\hline 3. & S003 & 10,0 & 20,0 & 12,5 & 7,5 & 50,0 & 15,0 & 25,0 & 15,0 & 15,0 & 70,0 \\
\hline 4. & S004 & 15,0 & 20,0 & 10,0 & 12,5 & $\mathbf{5 7 , 5}$ & 22,5 & 17,5 & 12,5 & 15,0 & 67,5 \\
\hline 5. & S005 & 12,5 & 15,0 & 10,0 & 12,5 & 50,0 & 17,5 & 22,5 & 12,5 & 15,0 & 67,5 \\
\hline 6. & S006 & 10,0 & 20,0 & 12,5 & 20,0 & 62,5 & 15,0 & 22,5 & 20,0 & 22,5 & 80,0 \\
\hline 7. & S007 & 12,5 & 12,5 & 17,5 & 20,0 & 62,5 & 17,5 & 20,0 & 20,0 & 25,0 & 82,5 \\
\hline 8. & S008 & 15,0 & 17,5 & 17,5 & 17,5 & 67,5 & 20,0 & 17,5 & 25,0 & 22,5 & 85,0 \\
\hline 9. & S009 & 20,0 & 20,0 & 12,5 & 17,5 & $\mathbf{7 0 , 0}$ & 25,0 & 25,0 & 15,0 & 15,0 & 80,0 \\
\hline 10. & S010 & 10,0 & 15,0 & 17,5 & 20,0 & 62,5 & 17,5 & 17,5 & 20,0 & 20,0 & 75,0 \\
\hline 11. & S011 & 10,0 & 17,5 & 20,0 & 12,5 & 60,0 & 15,0 & 25,0 & 22,5 & 12,5 & 75,0 \\
\hline 12. & S012 & 15,0 & 15,0 & 20,0 & 20,0 & $\mathbf{7 0 , 0}$ & 20,0 & 20,0 & 25,0 & 22,5 & 87,5 \\
\hline 13. & S013 & 10,0 & 12,5 & 7,5 & 20,0 & 50,0 & 15,0 & 25,0 & 10,0 & 25,0 & 75,0 \\
\hline 14. & S014 & 12,5 & 15,0 & 10,0 & 17,5 & 55,0 & 17,5 & 20,0 & 17,5 & 20,0 & 75,0 \\
\hline 15. & S015 & 17,5 & 12,5 & 20,0 & 15,0 & 65,0 & 22,5 & 20,0 & 22,5 & 10,0 & 75,0 \\
\hline 16. & S016 & 17,5 & 17,5 & 17,5 & 20,0 & 72,5 & 25,0 & 20,0 & 20,0 & 20,0 & 85,0 \\
\hline 17. & S017 & 17,5 & 20,0 & 10,0 & 15,0 & 62,5 & 22,5 & 25,0 & 12,5 & 17,5 & 77,5 \\
\hline 18. & S018 & 10,0 & 15,0 & 7,5 & 12,5 & 45,0 & 15,0 & 20,0 & 15,0 & 22,5 & 72,5 \\
\hline 19. & S019 & 10,0 & 20,0 & 12,5 & 12,5 & 55,0 & 15,0 & 22,5 & 15,0 & 20,0 & 72,5 \\
\hline 20. & S020 & 15,0 & 17,5 & 12,5 & 10,0 & 55,0 & 20,0 & 22,5 & 20,0 & 12,5 & 75,0 \\
\hline 21. & S021 & 12,5 & 10,0 & 0,0 & 20,0 & 42,5 & 17,5 & 17,5 & 17,5 & 22,5 & 75,0 \\
\hline 22. & S022 & 10,0 & 12,5 & 7,5 & 20,0 & 50,0 & 17,5 & 20,0 & 15,0 & 22,5 & 75,0 \\
\hline 23. & S023 & 17,5 & 15,0 & 15,0 & 12,5 & 60,0 & 22,5 & 22,5 & 17,5 & 12,5 & 75,0 \\
\hline 24. & S024 & 10,0 & 20,0 & 17,5 & 12,5 & 60,0 & 15,0 & 20,0 & 25,0 & 20,0 & 80,0 \\
\hline 25. & S025 & 15,0 & 17,5 & 10,0 & 20,0 & 62,5 & 20,0 & 12,5 & 12,5 & 25,0 & 70,0 \\
\hline 26. & S026 & 10,0 & 15,0 & 12,5 & 12,5 & 50,0 & 15,0 & 17,5 & 20,0 & 22,5 & 75,0 \\
\hline 27. & S027 & 12,5 & 12,5 & 10,0 & 20,0 & 55,0 & 20,0 & 20,0 & 12,5 & 17,5 & 70,0 \\
\hline 28. & S028 & 12,5 & 20,0 & 12,5 & 10,0 & 55,0 & 17,5 & 25,0 & 15,0 & 17,5 & 75,0 \\
\hline 29. & S029 & 15,0 & 12,5 & 5,0 & 10,0 & 42,5 & 20,0 & 15,0 & 12,5 & 15,0 & 62,5 \\
\hline 30. & S030 & 20,0 & 12,5 & 0,0 & 10,0 & 42,5 & 25,0 & 5,0 & 2,5 & 17,5 & 50,0 \\
\hline 31. & S031 & 10,0 & 15,0 & 5,0 & 12,5 & 42,5 & 15,0 & 17,5 & 12,5 & 17,5 & 62,5 \\
\hline 32. & S032 & 10,0 & 20,0 & 0,0 & 12,5 & 42,5 & 15,0 & 25,0 & 7,5 & 15,0 & 62,5 \\
\hline 33. & S033 & 15,0 & 10,0 & 5,0 & 12,5 & 42,5 & 22,5 & 15,0 & 7,5 & 17,5 & 62,5 \\
\hline 34. & S034 & 17,5 & 20,0 & 15,0 & 17,5 & 70,0 & 22,5 & 25,0 & 17,5 & 17,5 & 82,5 \\
\hline 35. & S035 & 15,0 & 12,5 & 12,5 & 17,5 & 57,5 & 20,0 & 17,5 & 20,0 & 17,5 & 75,0 \\
\hline 36. & S036 & 17,5 & 20,0 & 15,0 & 12,5 & 65,0 & 22,5 & 15,0 & 17,5 & 20,0 & 75,0 \\
\hline 37. & S037 & 17,5 & 12,5 & 12,5 & 20,0 & 62,5 & 22,5 & 15,0 & 20,0 & 17,5 & 75,0 \\
\hline 38. & S038 & 20,0 & 17,5 & 15,0 & 20,0 & 72,5 & 25,0 & 25,0 & 17,5 & 17,5 & 85,0 \\
\hline 39. & S039 & 20,0 & 20,0 & 12,5 & 17,5 & 70,0 & 25,0 & 17,5 & 15,0 & 22,5 & 80,0 \\
\hline 40. & S040 & 20,0 & 15,0 & 12,5 & 12,5 & 60,0 & 22,5 & 20,0 & 15,0 & 15,0 & 72,5 \\
\hline
\end{tabular}

Notes: 1. scores in identifying main ideas

2. scores in identifying suppoting details

3. scores in identifying moods of message

4. scores in developing new vocabularies 